\title{
PUTUSAN AHOK SEBUAH MAKNA KEHIDUPAN BERAGAMA DI INDONESIA
}

\section{Hardianto Djangih \\ Fakultas Hukum Universitas Tompotika Luwuk}

Kitab Undang-Undang Hukum Pidana (KUHP) merupakan produk kolonial Belanda, sebagaimana dikodifikasi dalam Sistem Hukum Nasional melaui Undnag-Undnag Nomor 1 Tahun 1946 tentang Peraturan Hukum Pidana. Menyimak usia keberadaan KUHP, bahwa telah berumur 71 (Tujuh Puluh satu tahun), lebih mudah 1 (satu tahun) usia kemerdekaan Indonesia. Namun, keberadaan Undang-undang tersebut sampai saat ini masih diberlakukan, yang menjadi pertanyaan, apakah karena dipandang masih sejalan dengan kehidupan masyarakat Indonesia? atau para ilmuan yang sampai saat ini belum mampu mendesain Hukum yang sesuai? ataukah pula Belum adanya kemauan lembaga legislatif untuk mendorong pengganti undang-undang tersebut?

Salah satu ketentuan pasal dalam KUHP tersebut yang saat ini sedang hangat diberpincangkan adalah Pasal 156 dan Pasal 156a KUHP. Isi ketentuan Pasal 156 KUHP "Barang siapa di muka umum menyatakan perasaan permusuhan, kebencian atau penghinaan terhadap suatu atau beherapa golongan rakyat Indonesia, diancam dengan pidana penjara paling lama empat tahun atau pidana denda paling banyak empat ribu lima ratus rupiah. Perkataan golongan dalam pasal ini dan pasal berikutnya berarti tiap-tiap bagian dari rakyat Indonesia yang berbeda dengan suatu atau beberapa bagian lainnya karena ras, negeri asal, agama, tempat, asal, keturunan, kebangsaan atau kedudukan menurut hukum tata negara." Pasal 156a "Dipidana dengan pidana penjara selama-lumanya lima tahun barang siapa dengan sengaja di muka umum mengeluarkan perasaan atau melakukan perbuatan: a. yang pada pokoknya bcrsifat permusuhan, penyalahgunaan atau penodaan terhadap suatu agama yang dianut di Indonesia; b. dengan maksud agar supaya orang tidak menganut agama apa pun juga, yang bersendikan Ketuhanan Yang Maha Esa. Menyimak ketentuan Pasal 156 dan 156a KUHP, mengatur tentang tindak pidana Penodaan Agama yang diakui di Indonesia.

Kita ketahui bersama bahwa Agama-agama yang diakui di Indonesia adalah: Agama Islam, Kriten, Protestan, Hindu, Buddha, dan Kong Hu Cu. Keberadaan Dasar keberadaadn agamaagama tersebut yaitu Pancasila dalam sila Pertama: "Ketuhanan Yang Maha Esa" prinsip keberadaan pemeluk agama diatur dalam Konstitusi (UUD Negara RI Tahun 1945) sebagaimana tercantum dalam Pasal 29 ayat (2) yaitu "Negara menjamin kemerdekaan tiap-tiap penduduk untuk memeluk agamanya masing-masing dan untuk beribadat menurut agamanya dan kepercayaannya itu". Artinya bahwa ada jaminan negara kepada setiap orang (WNI) untuk memeluk agama dan beribadat sesuai dengan agama dan kepercayaannya itu. Pemeluk keenam agama yang diakui di Indonesia, harus dapat menciptakan suasana toleransi antar umat beragama, 
menghargai dan menghormati akan keberadaan agama yang dianut oleh orang lain yang berbeda dengan agama yang dianutnya.

Sebagaimana disampaikan sebelumnya, bahwa Pasal 156 dan Pasal 156a KUHP menjadi hangat diperbincangkan dalam fenomena kasus Gubernur DKI Jakarta, Basuki Tjahaya Purnama (Ahok). Sebagaimana dalam perkembangan, kasus Ahok telah diputuskan Hakim Pengadilan Negeri Jakarta Utara dengan nomor: 1537/Pid.B/2016/PN. JKT.UTR yang dibacakan pada tanggal 9 Mei 2017. Dengan amar putusan MENGADILI menyatakan terdakwa Ir. BASUKI TJAHAJA PURNAMA alias AHOK terbukti secara sah dan meyakinkan bersalah melakukan tindak pidana Penodaan Agama; Menjatuhkan pidana kepada Terdakwa oleh karena itu dengan pidana penjara selama 2 (dua) Tahun; Memerintahkan agar Terdakwa ditahan; Menetapkan barang bukti yang diajukan oleh Penuntut Umum berupa : Seluruhnya tetap terlampir dan menjadi bagian tidak terpisahkan dari berkas perkara; Membebankan kepada Terdakwa untuk membayar biaya perkara sebesar Rp.5.000,- (lima ribu rupiah) ;

Kasus ini bermula pada kunjungan kerja Ahok sebagai Gubernur DKI Jakarta (Ahok terdaftar sebagai calon Kepada Daerah DKI Jakarta) pada salah satu wilayah di Propinsi DK Jakarta. Dalam kunjungan kerja tersebut Ahok menyampaikan sambutan. Adapun penggalan sambutannya adalah “... ini pemilihan kan dimajuin jadi kalo saya tidak terpilih pun saya berhentinya Oktober 2017 jadi kalo program ini kita jalankan dengan baik pun bapak ibu masih sempet panen sama saya sekalipun saya tidak terpilih jadi gubernur Jadi cerita ini supaya bapak ibu semangat, jadi ga usah pikiran ah..nanti kalau ga ke pilih, pasti Ahok programnya bubar, engga....saya sampai Oktober 2017, jadi jangan percaya sama orang, kan bisa aja dalam hati kecil bapak ibu ga bisa pilih saya, ya kan dibohongi pakai surat Al-Maidah 51, macem-macem itu itu hak bapak ibu yah jadi kalo bapak ibu perasaan gak bisa kepilih nih karena saya takut masuk neraka karna dibodohin gitu ya engga papa, karna inikan panggilan pribadi bapak ibu program ini jalan saja, jadi bapak ibu gak usah merasa gak enak, dalam nuraninya ga bisa milih Ahok, gak suka sama Ahok nih, tapi programnya gua kalo terima ga enak dong jadi utang budi jangan bapak ibu punya perasaan ga enak nanti mati pelan-pelan loh kena stroke." (dikutip dari lembaran putusan hakim nomor: 1537/Pid.B/2016/PN.JKT.UTR Pengadilan Negeri Jakarta Utara.

Jika disimak kata-kata yang disampaikan Ahok adanya perkataan "dibohongi Surat AlMaidah 51", yang artinya Surat Al-Maidah ayat 51 telah dipergunakan oleh orang lain untuk membohongi dan membodohi masyarakat dalam pemilihan kepala daerah, padahal Ahok sendiri yang mendudukkan atau menempatkan Surat Al-Maidah ayat 51 sebagai alat atau sarana untuk membohongi dan membodohi dalam proses pemilihan kepala daerah, karena menurut Ahok kandungan Surat Al-Maidah ayat 51 tidak ada hubungannya dalam memilih kepala daerah, dimana pendapat tersebut didasarkan pada pengalaman Ahok saat mencalonkan diri sebagai Gubernur Bangka Belitung, saat itu Ahok mendapatkan selebaran - selebaran yang pada 
pokoknya berisi larangan memilih pemimpin non muslim yang antara lain mengacu pada Surat Al-Maidah ayat 51 yang diduga dilakukan oleh lawan - lawan politik Ahok.

Surat Al-Maidah ayat 51 merupakan bagian dari Al Qur"an sebagai Kitab Suci agama Islam berdasarkan terjemahan Departemen/Kementerian Agama adalah "Wahai orang-orang yang beriman, janganlah kamu mengambil orang-orang Yahudi dan Nasrani menjadi pemimpinpemimpin(mu); sebahagian mereka adalah pemimpin bagi sebahagian yang lain. Barangsiapa diantara kamu mengambil mereka menjadi pemimpin, maka sesungguhnya orang itu termasuk golongan mereka. Sesungguhnya Allah tidak memberi petunjuk kepada orang-orang yang zalim.”, dimana terjemahan dan interpretasinya menjadi domain bagi pemeluk dan penganut agama Islam, baik dalam pemahamannya maupun dalam penerapannya.

Dengan fakta-fakta persidangan hakim menjerat Ahok dengan Pasal 156a KUHP dengan putusan pidana 2 tahun kurungan penjara. Namun, yang menarik dengan kasus ini Jaksa Penuntut Umum (JPU) menuntut Ahok dengan tuntutan alternatif yaitu: Pertama; Melanggar Pasal 156a KUHP, atau Kedua; Melanggar Pasla 156 KUHP. Dengan tuntutan alternative JPU, hakim memilih Pasal 156a KUHP yang rumusan pasalnya 1. Barang siapa; 2. Dengan sengaja; 3. Dimuka umum mengeluarkan perasaan atau melakukan perbuatan yang pada pokoknya bersifat permusuhan, penyalah-gunaan atau penodaan terhadap suatu agama yang dianut di Indonesia.

Putusan hakim terhadap kasus Ahok, jika kita kaji dari Tujuan Hukum, yaitu Keadilan, Kepastian dan Kemanfaatan. Maka dapat dikaji sebagai berikut:

Aspek Keadilan; Keadilan dapat diartikan sebagai memberikan hak yang setara dengan kapasitas seseorang atau pemberlakuan kepada tiap orang secara proporsional, Hukum tanpa keadilan tidaklah ada artinya sama sekali. Dalam Putusan hakim pada bagian awal disebutkan bahwa "Demi Keadilan Berdasarkan Ketuhanan Yang Maha Esa". Artinya bahwa hakim dalam mengadili sesuatu perkara akan berpedoman/berdasarkan kepada hukum, namun pertanggung jawaban akhir dari putusannya itu diserahkan kepada yang "gaib”, Tuhan Yang Maha Esa. Makna keadilan berfungsi sebagai penyeimbang terhadap kepentingan subyek hukum yang telah dilanggar oleh pembuat tindak pidana, sehingga pelaku tindak pidana dapat merasakan akibat dari perbuatannya. Kasus Ahok dari aspek keadilan, hakim telah memberi kesan positif bagi perlindungan hukum terhadap penganut agama yang telah menjadi sasaran dari perkataan ahok dalam sambutannya di Salah satu daerah di DKI Jakarta.

Aspek Kapastian, Kepastian merupakan harapan bagi pencari keadilan. Karena dengan kepastian hukum dapat diwujudkan melalui penormaan yang baik dan jelas dalam suatu undangundang dan akan jelas pula penerapanya. Dengan kata lain kepastian hukum itu berarti tepat hukumnya, subjeknya dan objeknya serta ancaman hukumanya. Jadi kalau dilihat kasus Ahok, hakim telah memberikan aspek kepastian, karena telah tepat menggunakan Pasal 156a atas kasus penodaan Agama yang dilakukan Ahok. 
Aspek Kemanfaatan, Kemanfaatan hukum perlu diperhatikan karena semua orang mengharapkan adanya manfaat dalam pelaksanaan penegakan hukum. Jangan sampai penegakan hukum justru menimbulkan keresahan masyarakat. Karena kalau kita berbicara tentang hukum kita cenderung hanya melihat pada peraturan perundang-undangan, yang terkadang aturan itu tidak sempurna adanya dan tidak aspiratif dengan kehidupan masyarakat. Putusan hakim atas Kasus Ahok dalam aspek kemanfaatan adanya sebuah penciptaan adanya prinsip menghargai dan menghormati terhadap ajaran agama yang dianut oleh ornag lain.

Dengan kajian ini penulis berharap, bahwa Indonesia sebagai negara hukum, maka setiap orang harus dapat mematuhi ketentuan hukum yang berlaku. Sehingga bagi siapa saja yang telah melakukan perbuatan melawan hukum tersebut, harus mampu mempertanggungjawabkan perbuatannya secara hukum. Sehingga hukum di Indonesia merupakan pedoman bertingkah laku bagi semua warganya negaranya. Dengan putusan Ahok tersebut, pesan yang disampaikan hakim, bahwa setiap pemeluk agama menghargai dan menghormati atas kepercayaan dan keyakinan agama orang lain dengan prinsip bahwa agama merupakan sebuah jaminan konstitusi bagi setiap warga negara.

\section{References}

Djanggih, H., \& Ahmad, K. (2017). The Effectiveness of Indonesian National Police Function on Banggai Regency Police Investigation (Investigation Case Study Year 2008-2016), Jurnal Dinamika Hukum. 17 (2), 152-157.

Thalib, H., Rahman, S., Mamulai, S., \& Djanggih, H. (2017). Verification Through the Electronic Media (Teleconference) on the Court in Criminal Judicial System. ADRI International Journal Of Law and Social Science, 1 (1), 1-9.

Djanggih, H. \& Saefudin Y. (2017). Pertimbangan Hakim pada Putusan Praperadilan: Studi Putusan Nomor: 09/PID. PRA/2016/PN. Lwk Tentang Penghentian Penyidikan Tindak Pidana Politik Uang. Jurnal Penelitian Hukum De Jure. 17 (3), 413-423.

Djanggih, H. (2013). Kebijakan Hukum Pidana Dalam Penanggulangan Cybercrime di Bidang Kesusilaan. Jurnal Media Hukum, 1 (2), 57-77.

Qamar, N., \& Djanggih, H. (2017). Peranan Bahasa Hukum dalam Perumusan Norma Perundang-undangan. Jurnal Ilmiah Kebijakan Hukum. 11 (3), 337-347.

Djanggih, H., \& Salle. (2017). Aspek Hukum Pengadaan Tanah bagi Pelaksanaan Pembangunan untuk Kepentingan Umum, Pandecta; Research Law Journal, 12 (2), 165-172.

Mamulai, M., Djanggih, H \& Wahab, M. (2017). Strength of Evidence of Electronic Media (Teleconference) In The Criminal Justice System, VRIJSPRAAK; International Law Journal, 1 (1), 1-20.

Thalib, H., Ramadhan, A., \& Djanggih, H. (2017). The Corruption Investigation In The Regional Police of Riau Islands, Indonesia, Rechtsidee, 4 (1). 